\title{
Hammondia isolated from dogs and foxes are genetically distinct
}

\author{
J. ABEL ${ }^{1}$, G. SCHARES ${ }^{2}$, K. ORZESZKO ${ }^{3}$, R. B. GASSER ${ }^{3,4}$ and J. T. ELLIS ${ }^{1 *}$ \\ ${ }^{1}$ Department of Cell and Molecular Biology, University of Technology, Sydney, Westbourne Street, Gore Hill, \\ NSW 2065, Australia \\ ${ }^{2}$ Institute of Epidemiology, Friedrich-Loeffler-Institut-Federal Research Institute for Animal Health, Seestrasse 55, \\ 16868 Wusterhausen, Germany \\ ${ }^{3}$ Department of Veterinary Science, The University of Melbourne, 250 Princes Highway, Werribee, Victoria 3030, Australia \\ ${ }^{4}$ Biotechnology Research Institute, Macquarie University, North Ryde, NSW 2109, Australia
}

(Received 5 May 2005; revised 26 Fuly 2005; accepted 27 Fuly 2005; first published online 27 September 2005)

\section{SUMMARY}

Hammondia heydorni is regarded as a protozoan parasite that uses canids, e.g. dogs and foxes, as definitive hosts, but clinical signs of infection are rare. This study therefore took advantage of the opportunity to study an oocyst population from the faeces of a dog suffering from intermittent bouts of diarrhoea. Oocysts from the naturally infected dog were shown to be $H$. heydorni by using the polymerase chain reaction combined with DNA sequencing as a diagnostic tool. $\dagger$ A comparison of the first internal transcribed spacer (ITS1) sequence of ribosomal DNA obtained with those from other dog and fox oocysts, previously regarded as $H$. heydorni, showed these oocysts contained identical ITS1 sequences. However, the oocyst DNA from the fox and dog differed by the presence/absence of a $9 \mathrm{bp}$ insertion/deletion within intron 1 of the alpha tubulin gene, and this difference was conserved across a number of different oocyst populations from the 2 species of host. A PCR assay was established that takes advantage of this insertion/deletion and is able to differentiate between the 2 oocyst populations. This study therefore provides evidence that $H$. heydorni oocysts from dogs and foxes represent 2 distinct genetic lineages that can be differentiated using a PCR, which targets the alpha tubulin locus.

Key words: Hammondia, Neospora, PCR, DNA sequencing, internal transcribed spacer, alpha tubulin gene, speciation.

\section{INTRODUCTION}

Hammondia heydorni is a cyst-forming coccidian parasite with an obligatory 2-host life-cycle (Heydorn, 1973; Fayer, 1974; Dubey and Fayer, 1976). In addition to dogs, also foxes and coyotes are regarded as definitive hosts in the parasite's life-cycle, whereas various herbivores were identified as intermediate hosts (Dubey et al. 2002a). Experimental data on a fox-derived Hammondia isolate suggest that infection of the definitive host occurs by ingestion of raw body tissues (e.g. raw meat) containing tissue cysts and leads to the shedding of unsporulated oocysts (Schares et al. 2003). Sporulation of oocysts can be detected within 3 days after their excretion in faeces (Blagburn et al. 1988), and intermediate hosts become infected by ingestion of the infective sporulated oocysts (Schares et al. 2002; Mohammed et al. 2003).

* Corresponding author: Department of Cell and Molecular Biology, University of Technology, Sydney, Westbourne Street, Gore Hill, NSW 2065, Australia. Tel: +612 9514 4161. Fax: +612 95144003. E-mail: john. ellis@uts.edu.au (J.T. Ellis)

$\dagger$ The nucleotide sequence data reported in this paper are available from GenBank under the following Accession numbers DQ183058, DQ183059 and DQ022687.
Hammondia heydorni is closely related to other coccidian parasites, such as Toxoplasma gondii, Neospora caninum and Hammondia hammondi. However, there is still considerable controversy about the taxonomy and phylogenetic relationships of these species and the taxonomic status of $H$. heydorni and $N$. caninum (see Ellis et al. 1999b; Dubey et al. $2002 a$; Heydorn and Mehlhorn, 2002).

In order to learn more about the biology of $H$. heydorni, new sensitive and specific methods such as serological tests and PCR are required (Slapeta et al. $2002 a$; Dubey et al. 2002a). PCR is a useful tool for the detection and identification of the cyst-forming coccidia (Ellis, 1998). In particular, the internal transcribed spacers (ITS) of rDNA or the alpha tubulin sequence have recently been reported as valuable genetic markers for the study of this species (Ellis et al. 1999b; Siverajah et al. 2002; Slapeta et al. 2002a). These sequences display reasonably high levels of conservation, yet there is sufficient sequence variation among related species to allow discrimination (e.g., Dubey et al. $2002 a$; Ellis and Pomroy, 2003).

Recently, Hammondia oocysts from foxes were compared with $H$. heydorni obtained from dogs. In contrast to the comparison of the ITS1, a comparison of partial large subunit ribosomal DNA sequences among Hammondia isolates from foxes 
and dogs showed them to be genetically different from each other (Schares et al. 2002; Mohammed et al. 2003). Although the number of nucleotide differences was low, these observations imply that either there may be considerable genetic diversity among $H$. heydorni isolates, as recently shown by Sreekumar et al. (2004), or that more than one species may exist within the taxon known as $H$. heydorni.

The present study describes the molecular characterization of oocysts shed by a naturally infected dog. The study, using PCR and sequencing of the ITS1, showed them to be consistent with H. heydorni. Partial sequencing of the alpha tubulin locus from these parasites was also performed, and the sequence obtained was compared with that derived from 2 oocyst populations obtained from experimentally infected foxes (designated Fox 2000/ 1, Schares et al. 2002; and HhO, Mohammed et al. 2003); as well as from another naturally infected dog (Siverajah et al. 2002; Ellis and Pomroy, 2003). The data show the oocysts from dog and from fox to be genetically distinct within intron 1 of the alpha tubulin gene. A PCR is also described, which takes advantage of an insertion/deletion found at this site that allows for the differentiation of the foxfrom the dog-derived Hammondia oocysts. This test should prove useful in the study of the prevalence and host distribution of these two parasite lineages, which are currently called H. heydorni.

\section{MATERIALS AND METHODS}

\section{Case study}

In October 2003, a dog (5-year-old, neutered female Hungarian Vizsla; body weight $26 \mathrm{~kg}$ ) with signs of haemolytic anaemia was presented in the Department of Veterinary Science of the University of Melbourne. Laboratory findings confirmed the clinical diagnosis and the dog was given immunosuppressive treatment (prednisolone $(20 \mathrm{mg})$, cyclosporine $(100 \mathrm{mg})$ twice per day and azothiaprine (50 mg) once daily) and supportive therapy for 10 days. During this time amoxycillin (500 mg) was also administered twice per day for 7 days. Subsequently, the dog was administered longterm treatment with azothiaprine and prednisolone. After discharge from hospital, the dog developed cystitis and recurrent bouts of diarrhoea. Bacterial culture of urine (obtained by cystocentesis) revealed Escherichia coli, and the cystitis was treated with therapeutic doses of enfloxacin. To investigate causative agents involved in the diarrhoea, coproscopical examinations were conducted. Examination by light microscopy revealed the presence of coccidian oocysts, which were subsequently purified by flotation on saturated zinc sulphate using standard methods.
The oocysts obtained (called HhM) from the dog were allowed to sporulate for 1 week in $2 \cdot 5 \%$ potassium dichromate $\left(\mathrm{K}_{2} \mathrm{CrO}_{4}\right)$, washed in phosphate-buffered saline (PBS) and then examined for ultraviolet autofluorescence (wavelength: 330$385 \mathrm{~nm}$ ) employing an Olympus BX51 microscope as described previously (Lindquist et al. 2003).

Twenty oocysts were examined by light microscopy and measured by standard procedures. The remaining oocysts were washed and resuspended in PBS, ruptured by vortexing them in an Eppendorf tube with glass beads (710-1180 $\mu \mathrm{m}$, Sigma) followed by multiple cycles of freeze/thaw. Subsequently, the sample was centrifuged and the supernatant transferred to a fresh tube, and an equal amount of lysis buffer $(10 \mathrm{~mm}$ Tris $\mathrm{pH} 8$, 100 mm EDTA pH 8, 1\% SDS) with Proteinase K $(100 \mu \mathrm{g} / \mathrm{ml})$ added. The sample was then incubated for $2 \mathrm{~h}$ at $56{ }^{\circ} \mathrm{C}$, after which it was extracted twice with a standard mix of phenol/chloroform/isoamyl alcohol $(25: 24: 1)$, and once with chloroform. The DNA was precipitated with ethanol, washed once with $70 \%$ ethanol, and then resuspended in sterile $10 \mathrm{~mm}$ Tris $-1 \mathrm{~mm}$ EDTA and stored at $-20^{\circ} \mathrm{C}$ for analysis.

\section{Other DNAs included in this study}

Genomic DNA obtained from oocysts shed by experimentally infected foxes (Fox 2000/1, Schares et al. 2002; HhO, Mohammed et al. 2003), a naturally infected dog (HhNZ; Ellis and Pomroy, 2003) and an experimentally infected dog (Giessen-1999; Schares et al. 2005) were also used in this study for comparative purposes. Genomic DNA from $N$. caninum (NC-1 strain) and $T$. gondii $(\mathrm{RH})$ were included as controls.

\section{PCR and DNA sequencing}

Purified genomic DNA was used as a template in the PCR. The ITS1 region was amplified as described previously (Ellis et al. 1999b; Ellis and Pomroy, 2003), using the primers TIM3 and TIM11.

For the amplification of a small fragment of the alpha tubulin gene spanning intron 1, primers AT9 (5"TGGCTGAGTAAGCACGGATTTTTC) and AT264 (5'GTGTCCTGTTCCCGCGTGTTGAT) were designed from gene sequence data reported by Siverajah et al. (2002). The specificity of the primers was evaluated using genomic DNA from Hammondia, N. caninum and T. gondii. A control containing no DNA was also performed, in order to exclude cross-contamination of any reagents. The $\mathrm{PCR}$ reaction contained $1 \times \mathrm{PCR}$ buffer (Finzyme), $250 \mu \mathrm{M}$ of each dNTP, 1U Dynazyme II F-501L polymerase (Finzyme), $20 \mu \mathrm{g} / \mathrm{ml}$ of bovine serum albumin (Fluka) in a volume of $25 \mu \mathrm{l}$. The PCR products were subjected 


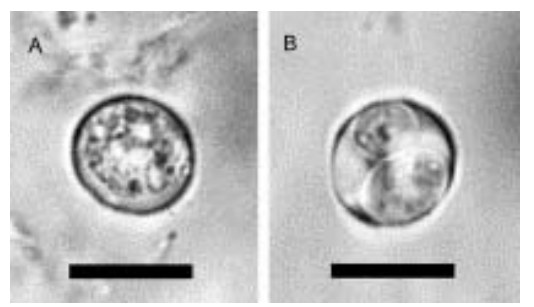

Fig. 1. Hammondia heydorni oocysts (HhM) shed by the naturally infected dog. Bar represents $10 \mu \mathrm{m}$. (A)

Unsporulated oocyst in water. (B) Sporulated oocyst containing 2 sporocysts in water.

to agarose $(1 \cdot 5 \%)$ gel electrophoresis in Tris borateEDTA buffer. For sequencing gel-purified (Qiagen gel extraction kit) amplification products were used. In the case of the Giessen-1999 isolate, unpurified amplification products were used. Amplicons were sequenced at least twice both directions. The PCR cycling conditions were $94{ }^{\circ} \mathrm{C}$ for $5 \mathrm{~min}$, followed by 50 cycles of $56^{\circ} \mathrm{C}$ for $1 \mathrm{~min}, 72{ }^{\circ} \mathrm{C}$ for $1 \mathrm{~min}$ and $94^{\circ} \mathrm{C}$ for $1 \mathrm{~min}$. The PCR was finished with $56{ }^{\circ} \mathrm{C}$ for $1 \mathrm{~min}$ and a final extension at $72{ }^{\circ} \mathrm{C}$ for $5 \mathrm{~min}$.

The program AssemblyLign ${ }^{\mathrm{TM}}$ (International Biotechnologies) was used to align ITS1 or tubulin sequences, and the consensus sequences obtained were compared against sequences deposited in the NCBI (National Centre of Bioinformatics) database using the program Blast $\mathrm{N}$.

\section{RESULTS}

\section{Case study}

Microscopical examination of the faeces from the dog revealed oocysts consistent with $H$. heydorni or $N$. caninum, based on morphological characteristics. In water the thick-walled oocysts were $11.4 \pm 0.5 \times 12.3 \pm 0.6 \mu \mathrm{m}$ in size (mean \pm standard deviation) and contained 2 sporocysts (and 4 sporozoites in each sporocyst) after sporulation (Fig. 1). This morphology was consistent with that described for N. caninum, H. heydorni and T. gondii (see Lindsay, Upton and Dubey, 1999). The oocysts showed autofluorescence under ultraviolet light.

The ITS1 region amplified from HhM oocyst DNA was $\sim 600 \mathrm{bp}$ in size. The PCR product was sequenced and an investigation of present sequence databases with the consensus sequence (475 bp GenBank Accession number DQ183058) revealed $100 \%$ identity with/to previous ITS1 sequences from H. heydorni from canids (GenBank Accession no. AY189897, Giessen-1999; AF508030, HhNZ).

The species specificity of primers AT9 and AT264 was assessed by PCR using genomic DNA from Hammondia, N. caninum and $T$. gondii. A PCR product was only obtained from Hammondia oocysts under the conditions tested (Fig. 2). The partial
A

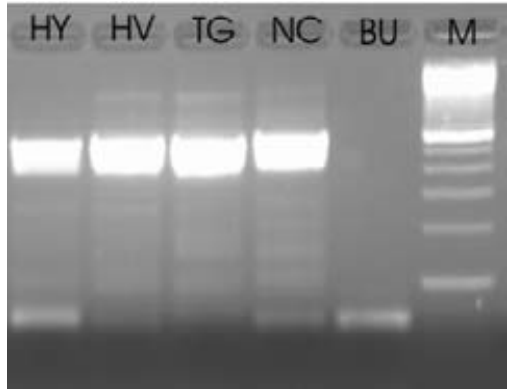

TIM3-TIM11

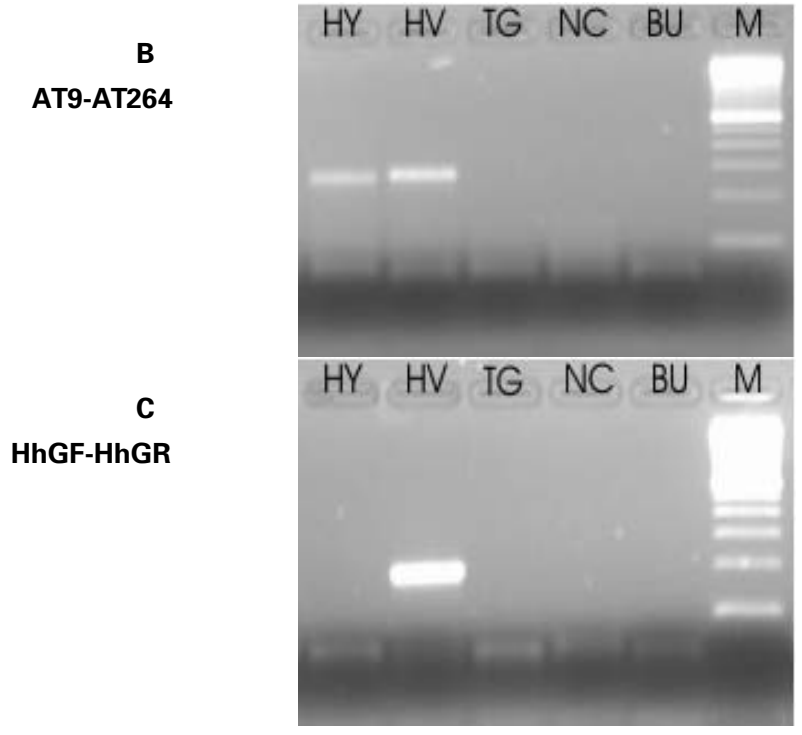

Fig. 2. PCR of genomic DNA from cyst-forming coccidia using 3 different primer pairs. HY, H. heydorni Giessen-1999; HV, Hammondia sp. Fox-2000/1 ; TG, Toxoplasma gondii (RH strain); NC, Neospora caninum (NC-1 strain); BU, No DNA negative control; M, molecular weight marker comprising a $100 \mathrm{bp}$ ladder. All DNAs produce a PCR product with primers TIM3/ TIM11 (A), while only Hammondia DNA gives a product with primers AT9 and AT264 (B). DNA derived from Hammondia oocysts shed by foxes produce a PCR product with primers $\mathrm{HhGF}$ and HhGR (C).

alpha tubulin sequence (Accession no. DQ183059) obtained from HhM PCR products (using AT9 and AT264) was the same as that determined previously (Accession no. AY169962). This DNA was extracted from oocysts found in the faeces of a naturally infected dog from New Zealand (HhNZ; Siverajah et al. 2002; Ellis and Pomroy, 2003). An identical sequence was obtained for the alpha tubulin gene spanning intron 1 from H. heydorni Giessen-1999 (Accession number DQ022687). Based on these PCR and DNA sequencing data results, the evidence shows the oocyst sample HhM is genetically consistent with $H$. heydorni.

\section{Comparison of tubulin sequences}

Comparison of the 3 partial alpha tubulin sequences obtained from dog oocysts (samples HhM, HhNZ and Giessen-1999) with those determined from 
HhM

HhNZ

Fig. 3. Comparison of partial $\alpha$ tubulin gene sequences from 5 isolates of Hammondia heydorni (HhM, oocysts from this study; HhNZ from Ellis and Pomroy (2003); Fox 2000/1 described by Schares et al. (2002); HhO described by Mohammed et al. (2003); Giessen-1999 described by Schares et al. (in preparation). The repetitive sequence is in bold and underlined. The fox sequences contain 2 copies of this repeat, whereas the dog sequences contain only 1 . Sequence orientation is 5 to $3^{\prime}$.

2 populations of fox oocysts (HhO and FOX 2000/1) showed that both of the latter sequences contained a 9-bp insertion (TCCATGCAC) (Fig. 3). This difference in size was detectable upon agarose gel $(1.5 \%)$ electrophoresis of the PCR products (not shown). Eight of the bases found in this insertion were also present in the sequence present immediately following the site of insertion. In order to confirm the presence/absence of the insertion/ deletion amongst the isolates, PCR primers were designed (HhGF, 5'CGCATTCAAAAAGTGCCACAATTG; HhGR, 5'ACTCCATGCACACATATGCAT) which should exclusively produce a PCR product from DNA of fox oocysts because HhGR bridges the region corresponding to the insertion/deletion. As shown in Fig. 2, a PCR product was obtained exclusively from Fox 2000/1 DNA only. No PCR products were amplified from $H$. heydorni DNA extracted from dog-derived oocysts, $T$. gondii, $N$. caninum or from the no-DNA control.

\section{DISCUSSION}

Clinical cases of hammondiosis in dogs are rare. This study therefore took advantage of the opportunity to study an oocyst population from the faeces of a dog suffering from intermittent bouts of diarrhoea. This dog had previously been treated for haemolytic anaemia, and it is interesting to note that others have previously suggested that the immunosuppressive treatment for this disease had rendered another dog susceptible to toxoplasmosis (Webb et al. 2005).

The purified, sporulated oocysts obtained were $11 \cdot 4 \pm 0.5 \times 12.3 \pm 0.6 \mu \mathrm{m}$ in size, when measured in water, contained 2 sporocysts and had a thick, colourless wall. These morphological features are consistent with the morphology of oocysts of $T$. gondii (from felids), H. heydorni (from canids) and N. caninum (from canids) (Lindsay et al. 1999). Similar-sized oocysts from these species $(12.6 \times$ $11.9 \mu \mathrm{m}$ and $10-14 \cdot 1 \times 9 \cdot 2-13 \cdot 1 \mu \mathrm{m}$ respectively) respectively are indistinguishable by light microscopy (Heydorn, 1973; Blagburn et al. 1988). The structure of the sporulated oocysts is also similar among all 3 species, containing 2 sporocysts and 4 sporozoites/sporocyst.

A great deal of discussion about the taxonomic status of $H$. heydorni and $N$. caninum arose from the discovery of $N$. caninum oocysts in the faeces of dogs (McAllister et al. 1998; Mehlhorn and Heydorn, 2000; Heydorn and Mehlhorn, 2002). However, it is now generally accepted that at least 2 Hammondia-/Neospora-like species with morphologically similar oocyst stages but with distinct biological, immunological, ultrastructural and molecular features use the $\operatorname{dog}$ as definitive host (reviewed by Dubey et al. $2002 a, b$ ). Nevertheless, doubts remain as to whether studies on H. heydornilike oocysts conducted before 1998 were performed using a homogeneous population of parasites. For instance, Müller et al. (2001) verified by PCR methodologies that the isolate originally designated as $H$. heydorni-Berlin-1996 contained N. caninum.

Molecular tools can assist in making a specific identification of a species of a parasite present in clinical specimens (Ellis, 1998). The ITS1 rDNA region has repeatedly proven useful for the specific identification of coccidian species (Holmdahl and Mattson, 1996; Payne and Ellis, 1996; Buxton et al. 1998; Ellis et al. 1999a; Slapeta et al. 2002a,b; Ellis and Pomroy, 2003; Mohammed et al. 2003). Thus this locus was therefore amplified and sequenced from the oocyst sample HhM. Database searches revealed that the sequence determined herein was identical to that obtained from 2 other H. heydorni isolates (AY189897, AF508030). The ITS1 sequence was therefore consistent with $H$. heydorni. These findings were supported by the analysis of partial alpha tubulin sequences, which upon database searches also showed complete identity to a sequence from another $H$. heydorni isolate from a naturally infected dog (AY169962) (Siverajah et al. 2002; Ellis and Pomroy, 2003). As shown in the present study, the alpha tubulin gene spanning intron 1 from another dog-derived H. heydorni isolate (Giessen-1999) was also identical to both that of HhM and HhNZ. 
Genetic analysis of the large subunit of rDNA from oocysts found in the faeces of an Arabian red fox (Mohammed et al. 2003) confirmed the identification of sequence divergence in the rDNA of Hammondia reported by Schares et al. (2002). As the latter sequence is considered to be highly conserved between species, analysis of another conserved locus, the alpha tubulin gene, was also included in this present study. Although the precise structure of the Hammondia alpha tubulin gene is unknown, by comparison to the $N$. caninum gene, the region analysed spans what is predicted to be intron 1 (Siverajah et al. 2002). The alpha tubulin sequence obtained from the dog oocysts (samples HhM, HhNZ and Giessen-1999) were compared with those obtained from 2 oocyst populations obtained from foxes (Schares et al. 2002; Mohammed et al. 2003). Analysis by agarose gel electrophoresis revealed that the PCR products were slightly different in size. Subsequent sequencing confirmed this finding by showing that the sequences generated from the two different oocyst populations obtained from foxes both had an insert of $9 \mathrm{bp}$ (TCCATGCAC) when compared with that obtained from the dog oocysts. PCR of oocyst DNA using a primer spanning the region of the insertion/deletion gave a product for the oocysts from fox but not from the oocysts from dog thereby confirming the presence of the deletion. Taken together, the results of the present study suggest that $H$. heydorni-like oocysts from dogs are genetically different from those shed by foxes. A large-scale evaluation including extended sets of isolates from dog and fox need to be examined to test the present proposal.

A recent study of sequence polymorphisms found in a variety of introns (including those of the alpha tubulin locus) among different isolates of $T$. gondii concluded these polymorphisms correlated with distinct clonal lineages ( $\mathrm{Su}$ et al. 2003). This consideration may also apply to these $H$. heydorni-like organisms, which during speciation may have evolved into 2 genetically distinct lineages: one uses dogs as definitive dogs and one employing foxes. Nevertheless, before conclusions regarding the existence of another species of Hammondia can be made, further research should focus on establishing whether biological, ecological and epidemiological differences exist between them.

Part of this work was carried out by J.A. as an undergraduate research project for the University of Regensburg, while at the University of Technology, Sydney. We thank Andrea Bärwald for technical assistance. We thank Leonie Richards (Melbourne University) for referring this case to us.

\section{REFERENCES}

Blagburn, B. L., Lindsay, D. S., Swango, L. J., Pidgeon, G. L. and Braund, K. G. (1988). Further characterization of the biology of Hammondia heydorni. Veterinary Parasitology 27, 193-198.

Buxton, D., Maley, S. W., Wright, S., Thomson, K. M., Rae, A. G. and Innes, E. A. (1998). The pathogenesis of experimental neosporosis in pregnant sheep. Fournal of Comparative Patholology 118, 267-279.

Dubey, J. P. and Fayer, R. (1976). Development of Isospora bigemina in dogs and other mammals. Parasitology 73, 371-380.

Dubey, J. P., Barr, B. C., Barta, J. R., Bjerkås, I., Björkman, C., Blagburn, B. L., Bowman, D. D., Buxton, D., Ellis, J. T., Gottstein, B., Hemphill, A., Hill, D. E., Howe, D. K., Jenkins, M. C., Kobayashi, Y., Koudela, B., Marsh, A. E., Mattsson, J. G., McAllister, M. M., Modrỳ, D., Omata, Y., Sibley, L. D., Speer, C. A., Trees, A. J., Uggla, A., Upton, S. J., Williams, D. J. L. and Lindsay, D. S. (2002a). Redescription of Neospora caninum and its differentiation from related coccidia. International Fournal for Parasitology 32, 929-946.

Dubey, J. P., Hill, D. E., Lindsay, D. S., Jenkins, M. C., Uggla, A. and Speer, C. A. (2002b). Neospora caninum and Hammondia heydorni are separate species/ organisms. Trends in Parasitology 18, 66-69.

Ellis, J. (1998). Polymerase chain reaction approaches for the detection of Neospora caninum and Toxoplasma gondii. International Fournal for Parasitology 28, 1053-1060.

Ellis, J. T., McMillan, D., Ryce, C., Payne, S., Atkinson, R. and Harper, P. A. W. (1999a). Development of a single tube nested polymerase chain reaction assay for the detection of Neospora caninum DNA. International Fournal for Parasitology 29, 1589-1596.

Ellis, J. T., Morrison, D. A., Liddell, S., Jenkins, M. C., Mohammed, O. B., Ryce, C. and Dubey, J. P. $(1999 b)$. The genus Hammondia is paraphyletic. Parasitology 118, 357-362.

Ellis, J. T. and Pomroy, W. E. (2003). Hammondia heydorni oocysts in the faeces of a greyhound in New Zealand. New Zealand Veterinary Fournal 51, 38-39.

Fayer, R. (1974). Development of Sarcocystis fusiformis in the small intestines of the dog. Fournal of Parasitology 60, 660-665.

Heydorn, A. O. (1973). Zum Lebenszyklus der kleinen Form von Isospora bigemina des Hundes. Rind und Hund als mögliche $Z$ wischenwirte. Berliner und Münchner Tierärztliche Wochenzeitschrift 86, 323-329.

Heydorn, A. O. and Mehlhorn, H. (2002). Neospora caninum is an invalid species name: an evaluation of facts and statements. Parasitology Research 88, 175-184.

Holmdahl, O. J. M. and Mattsson, J. G. (1996). Rapid and sensitive identification of Neospora caninum by in vitro amplification of the internal transcribed spacer 1 . Parasitology 112, 177-182.

Lindquist, H. D., Bennett, J. W., Hester, J. D., Ware, M. W., Dubey, J. P. and Everson, W. V. (2003). Autofluorescence of Toxoplasma gondii and related coccidian oocysts. Fournal of Parasitology 89, 865-867.

Lindsay, D. S., Upton, S. J. and Dubey, J. P. (1999). A structural study of the Neospora caninum oocyst. International Fournal for Parasitology 29, 1521-1523. 
McAllister, M. M., Dubey, J. P., Lindsay, D. S., Jolley, W. R., Wills, R. A. and McGuire, A. M. (1998). Dogs are definitive hosts of Neospora caninum. International Fournal for Parasitology 28, 473-478.

Mehlhorn, H. and Heydorn, A. O. (2000). Neospora caninum: is it really different from Hammondia heydorni or is it a strain of Toxoplasma gondii? An opinion. Parasitology Research 86, 169-178.

Mohammed, O. B., Davies, A., Hussein, H. S., Daszak, P. and Ellis, J. T. (2003). Hammondia heydorni from the Arabian Mountain Gazelle and Red Fox in Saudi Arabia. Fournal of Parasitology 89, 535-539.

Müller, N., Sager, H., Hemphill, A., Mehlhorn, H., Heydorn, A. O. and Gottstein, B. (2001). Comparative molecular investigation of Nc5-PCR amplicons from Neospora caninum NC-1 and Hammondia heydorniBerlin-1996. Parasitology Research 87, 883-885.

Payne, S. and Ellis, J. T. (1996). Detection of Neospora caninum DNA by the polymerase chain reaction. International Fournal for Parasitology 26, 347-351.

Schares, G., Heydorn, A. O., Cüppers, A., Mehlhorn, H., Geue, L., Peters, M. and Conraths, F. J. (2002). In contrast to dogs, red foxes (Vulpes vulpes) did not shed Neospora caninum upon feeding intermediate host tissues. Parasitology Research 88, 44-52.

Schares, G., Meyer, J., Bärwald, A., Conraths, F. J., Riebe, R., Bohne, W., Rohn, K. and Peters, M. (2003). A Hammondia-like parasite from the European fox (Vulpes vulpes) forms biologically viable tissue cysts in cell culture. International Fournal for Parasitology 33, 229-234.

Schares, G., Pantcher, N., Barutzki, D., Heydorn, A. O., Bauer, C. and Conraths, F. J. (2005). Neospora caninum, Hammondia heydorni, Toxoplasma gondii and
Hammondia hammondi oocysts in the faeces of naturally infected dogs in Germany. International Fournal for Parasitology (in the Press).

Siverajah, S., Ryce, C., Morrison, D. A. and Ellis, J. T. (2002). Characterization of an alpha tubulin gene sequence from Neospora caninum and Hammondia heydorni, and their comparison to homologous genes from Apicomplexa. Parasitology 126, 561-569.

Slapeta, J. R., Koudela, B., Votypka, J., Modrỳ, D., Horejs, R. and Lukes, J. (2002a). Coprodiagnosis of Hammondia heydorni in dogs by PCR based amplification of ITS 1 rRNA: differentiation from morphologically indistinguishable oocysts of Neospora caninum. Veterinary Fournal 163, 147-154.

Slapeta, J. R., Modrỳ, D., Kyselova, I., Horejs, R., Lukes, J. and Koudela, B. (2002b). Dog shedding oocysts of Neospora caninum: PCR diagnosis and molecular phylogenetic approach. Veterinary Parasitology 109, 157-167.

Sreekumar, C., Hill, D. E., Miska, K. B., Rosenthal, B. M., Vianna, M. C. B., Venturini, L., Basso, W., Gennari, S. M., Lindsay, D. S. and Dubey, J. P. (2004). Hammondia heydorni: evidence of genetic diversity among isolates from dogs. Experimental Parasitology 107, 65-71.

Su, C., Evans, D., Cole, R. H., Kissinger, J. C., Ajioka, J. W. and Sibley, L. D. (2003). Recent expansion of Toxoplasma through enhanced oral transmission. Science 299, 414-416.

Webb, J. A., Keller, S. L., Southorn, E. P., Armstrong, J., Allen, D. G., Peregrine, A. S. and Dubey, J. P. (2005). Cutaneous manifestations of disseminated toxoplasmosis in an immunosuppressed dog. Fournal of the American Animal Hospital Association 41,198-202. 